\title{
Tesla Motors:
}

\section{A Potentially Disruptive Force in a Mature Industry}

Nicholas Ingram,

\author{
Barcelona School of Management, Universitat Pompeu Fabra
}

\begin{abstract}
The purpose of this paper is to analyse Tesla's strategy for ensuring own sustainable future growth, while acting as a catalyst of change in the automotive industry. The paper utilises the document analysis as a main method, with the presentation of the results in a case study format. It was realised that Tesla has managed to create a product that has a rather unique positioning in a highly competitive industry. However, Tesla was unable to capitalise on the potential demand regardless of superiority of its products, as the current market leaders have a considerably lower price and are competing with a different class of vehicles altogether. The implications for industry development are discussed in connection with competition in Hybrid Electric Vehicle and Battery Electric Vehicle categories.
\end{abstract}

Keywords: Disruptive Force, Automotive Industry, Tesla, Electric Vehicles, Competition 


\section{Introduction}

Tesla Motors is one of the leading innovators in the Electric Vehicle market. It is a modern and potentially disruptive entrant into the mature automotive industry that has benefited from hundreds of years of research and development and astronomical amounts of funding.

\section{Methodological Approach}

This paper aims to provide an effective analysis of the current position of Tesla Motors in regards to the company's competitive advantage in a global context. An industry analysis was undertaken followed by an analytical breakdown of the influences in the current internal and external environments, with the focus on factors that affect the firm's strategy. A framework is developed to facilitate a better understand the opportunities for strengthening the company's positioning, supported by the discussion of practical implications for industry development in regards to competition in Hybrid Electric Vehicle and Battery Electric Vehicle categories.

Firstly, a concise overview of the company is provided including a brief history focused on how the company came to be one of the leading innovators in the electric vehicle and energy storage industries. Following this, an overview of the industry is presented in addition to a summary of Tesla's partnerships, main competitors and strategic options. The discussion of practical implications aims at raising competitiveness of the company and is structured around the latest research in the automotive industry and the emerging electric vehicle market.

\subsection{Scope and Limitations}

Although Tesla motor's product range includes electric cars, automobile components and rechargeable energy storage systems this report has its focus primarily on the automobile industry. In addition to this, the analysis of the internal environment is not going beyond analysing the company's current offerings and target market as there is limited access to data regarding the firm's strategy readily available online or in publications. As Tesla's products in this industry compete with fossil fuel and hybrid and battery electric vehicles, information regarding the automotive industry as a whole will be provided illustrating the potential growth of the market sector in future years. Data shall primarily focus on the U.S. market for ease of comparison.

\section{The Company}

\subsection{History and Ethos}

Tesla is a US based technology company founded in 2003 that manufactures automobiles and sells automotive components and energy storage devices derived largely from its own patented technology. The company's auto-manufacturing department differentiates itself from traditional firms in the sector by voicing their concern for the environmental impact of fossil fuel powered vehicles and stating that over reliance on, and investment in developing combustion engines has inhibited innovation in alternative fuel power train technologies (Tesla Motors, 2015; Musk,

International Journal of Management and Applied Research, 2018, Vol. 5, No. 1 
2015). For this reason Tesla focuses solely on developing battery electric vehicles, while other large firms within the industry invest heavily into hybrid, plug in hybrid and alternative fuel cell vehicles.

\subsection{Value Preposition}

The company's value proposition is derived from having a luxury car with specifications comparable to high end luxury vehicles, without having the large amounts of pollution on the consumers' conscience; in addition to making driving greener without compromising on the performance, electricity is more affordable than fossil fuels in most markets. Electric vehicles also have fewer moving parts than their fossil fuel competitors and it is argued that they require less servicing and maintenance making them more affordable to run when compared with traditional cars over a products lifetime (Chan and Wong, 2004).

\subsection{Strategic Concept}

The company's original strategic concept was to emulate the typical life cycles of products in the technology industry and have the research and development of new products paid for by previous products sales. Tesla is hoping to achieve this through the implementation of a three stage development strategy of the firm's products that is in unison with Roger's (2003) Diffusion of Innovation Theory.

Firstly, the innovators were targeted with the Tesla Roadster; a high-priced, high performance electric sports car and had a low volume of production. Following this by the Model S, a mid-priced sedan with a medium level of production, was produced as a more practical car to further target the innovators. According to Rogers the innovators have more of less embraced the concept of green cars within the USA as figures suggest that HEVs, PHEVs and BEVs have an adoption rate of just over 2.5\% (Cobb, 2015). The soon to be released Model 3 an affordable relatively low-priced automobile which will be produced in high volumes, is aimed at targeting the early adopters as the technology becomes more widely accepted and the benefits versus cost of adoption is more widely understood (Rogers, 2003; Musk, 2006). The company implies that if you are purchasing any model of Tesla automobile you are investing in the development of future models and consequently making green technology more affordable, which further adds value to the idea of purchasing a Tesla product. The firm have slightly deviated from this strategy presumably in order to adapt to customer demand within the market and have developed the Model X, a utility vehicle which recent trends suggest have grown in popularity and have overtaken sedans as the most popular body type of new vehicle to be registered in the USA (IHS Automotive, 2014). Table 1 summarises retail market share by body type.

Table 1: Retail market share by body type

\begin{tabular}{lrrrrrr}
\hline \multicolumn{2}{c}{$\mathbf{2 0 0 9}$} & $\mathbf{2 0 1 0}$ & $\mathbf{2 0 1 1}$ & $\mathbf{2 0 1 2}$ & $\mathbf{2 0 1 3}$ & $\mathbf{2 0 1 4}$ \\
\hline SUV & $31.40 \%$ & $33.60 \%$ & $34.40 \%$ & $33.30 \%$ & $33.90 \%$ & $36.50 \%$ \\
Sedan & $36.30 \%$ & $36.20 \%$ & $36.50 \%$ & $36.50 \%$ & $36.60 \%$ & $35.40 \%$ \\
Pickup & $14.10 \%$ & $13.80 \%$ & $12.70 \%$ & $12.80 \%$ & $13.60 \%$ & $13.10 \%$ \\
Hatchback & $5.60 \%$ & $5.00 \%$ & $6.20 \%$ & $6.60 \%$ & $6.00 \%$ & $5.50 \%$ \\
Van & $5.00 \%$ & $4.00 \%$ & $3.90 \%$ & $3.90 \%$ & $3.60 \%$ & $3.60 \%$
\end{tabular}

International Journal of Management and Applied Research, 2018, Vol. 5, No. 1 


\begin{tabular}{llllllr} 
Coupe & $4.50 \%$ & $4.60 \%$ & $3.60 \%$ & $3.80 \%$ & $3.50 \%$ & $3.40 \%$ \\
Station Wagon & $1.10 \%$ & $1.20 \%$ & $1.30 \%$ & $1.70 \%$ & $1.30 \%$ & $1.20 \%$ \\
\hline
\end{tabular}

The company differentiates itself from the standard dealership model currently dominating the US automobile market by vertically integrating the sales operations. Traditionally automobile manufacturers have to sell their products through third party dealerships and franchises (Bodisch, 2009). However, Tesla encourages online sales and is the only car dealership that has set up methods of direct customer sales. In states where the direct sale of cars by auto manufacturers is illegal or restricted, Tesla have opened up so called "Galleries" with the intention of merely providing a place for potential customers to come and view the product before purchasing it online. This has met considerable criticism from law makers and other manufacturers but the unique position Tesla has created seems to be stable as other manufacturers are adopting similar sales models (Read, 2013). This issue is unique to the US market due to the unique model of car sales but is relevant as this is currently Tesla's largest market.

\subsection{Important Partnerships}

Daimler AG, best known as the maker of Mercedes vehicles acquired a financial stake in Tesla in 2010 with the notion of collaboration "on the development of battery systems, electric drive systems and on individual projects" (Tesla Motors, 2015). This included the development of battery packs and charging equipment for the Smart Fortwo and the Mercedes-Benz A-class.

Toyota Motor Corporation, the world's biggest automaker had similar partnership arrangements with Tesla. After acquiring a financial stake in the company, Toyota had Tesla develop powertrain systems for its RAV4 Programme. Tesla acquired a large manufacturing facility for bellow the market rate from Toyota as part of the partnership agreement, which entitled Tesla to federal loans given to companies developing emissions free, high efficiency vehicles. Both these partnerships both came about at extremely important times for Tesla as they were worth a considerable amount financially and Tesla was able to capitalise on this and invest heavily into developing its product range (Trudell and Ohnsman, 2014; Tesla Motors, 2014).

Tesla has an ongoing strategic partnership with Panasonic, a leading company in battery technologies, where they are cooperating on the construction of a facility known as the Gigafactory. The strategic value of this partnership is extremely high as the purpose of the facility is to insure the continuous supply of battery components in order to meet the rising demand for Tesla vehicles, in addition to innovation and cost reduction of the components for use in future Tesla models aimed at the mass market (Tesla Motors, 2014a). The Gigafactory will be operational by 2020 and will be working to supply batteries for an estimated 500,000 Tesla cars per year whilst working at $30 \%$ capacity. There is scope and willingness from executives to further expand the site by 50 to $100 \%$, making the Tesla, Panasonic partnership the largest manufacturer of lithium-ion fuel cells (Cuthbertson, 2014; Tesla Motors, 2014b). Additional information regarding Tesla's strategic partnerships can be found in the table 2 .

International Journal of Management and Applied Research, 2018, Vol. 5, No. 1 
Table 2: Overview of Partnerships

\begin{tabular}{|c|c|c|c|}
\hline Partner & $\begin{array}{l}\text { Type of } \\
\text { Partnership }\end{array}$ & Purpose & Synergy \\
\hline $\begin{array}{l}\text { Daimler AG } \\
(2007-2014)\end{array}$ & $\begin{array}{l}\text { Strategic } \\
\text { partnership }\end{array}$ & 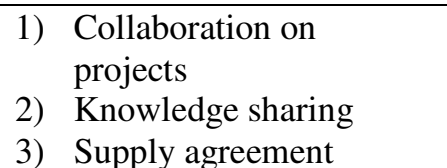 & $\begin{array}{l}\text { High level of synergy, } \\
\text { indicating a successful } \\
\text { partnership. }\end{array}$ \\
\hline $\begin{array}{l}\text { Toyota } \\
\text { Motor } \\
\text { Corporation } \\
\text { (2010-2015) }\end{array}$ & Investment & $\begin{array}{l}\text { 1) Collaboration on Toyota } \\
\text { RAV4 EV } \\
\text { 2) Knowledge share } \\
\text { 3) Supply agreements }\end{array}$ & $\begin{array}{l}\text { High level of synergy, } \\
\text { indicating a successful } \\
\text { partnership. }\end{array}$ \\
\hline $\begin{array}{l}\text { Panasonic } \\
\text { corporation } \\
\text { (2014- } \\
\text { Present) }\end{array}$ & $\begin{array}{l}\text { Strategic } \\
\text { partnership }\end{array}$ & $\begin{array}{l}\text { 1) Battery research and } \\
\text { Development } \\
\text { 2) Gigafactory }\end{array}$ & N/A \\
\hline Airbnb & Investment & Expand charger availability & $\begin{array}{l}\text { Medium level of synergy } \\
\text { indicating considerable } \\
\text { benefits to both parties. }\end{array}$ \\
\hline
\end{tabular}

\section{Industry Analysis}

\subsection{Overview}

Tesla Motors competes within a niche market in the automotive industry. The auto industry has seen considerable growth in demand since the financial crisis with many manufacturing companies competing for lost market share. In 2014, approximately 7.9 million vehicles were sold in the U.S. market (see Figure 1), bringing sales to their highest level since 2002 (Autoalliance, 2015). Raising oil prices in 2008 also made consumers more aware of vehicles consumption and the market for sustainable, highly efficient cars has grown as a result of that (Economist, 2009).

Luxury model sales have exceeded industry growth rates by $2.8 \%$ in the first three months of 2015 in the USA, which could be due to the fall in crude oil prices and therefore cheaper petrol (Murtha, 2015). BMW and Mercedes currently lead in the luxury car market in the United States but face increasing competition from other brands such as Lexus and Audi (see Figure 1).

Figure 1: Luxury Car Market Share \% by Brand 2014

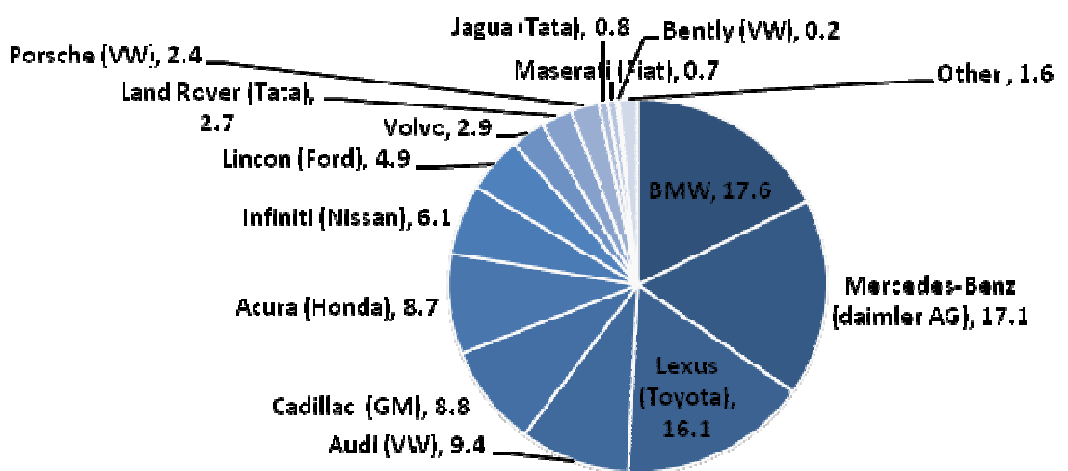

Source: GoodCarBadCar, 2015

International Journal of Management and Applied Research, 2018, Vol. 5, No. 1 
The demand for hybrid and battery electric cars has seen considerable global growth in recent years with many companies capitalising on this trend and investing heavily into the new technology. This seems to be in line with fluctuations of oil prices, access to government loans for the purpose of investing in renewables and government subsidies for customers purchasing electric cars.

In 2014 and so far in 2015 the demand for hybrid and electric cars has declined in the USA (EDTA, 2015). This may be due to decreasing oil prices and therefore cheaper access to fossil fuels or customer's apprehensions regarding the current specifications of electric cars; more specifically the overall time in which it takes to refuel the cars and their range respectively. The European market continues to see a rise in demand for electric vehicles, likely due to the fact that fuel is more heavily taxed in Europe than the USA (Pyper, 2015). In addition to this, there has again been increased interest in automobile emissions in recent months due to controversy and alleged fraud by industry giants regarding deasil emissions this may have an impact on sales of hybrids and battery electric vehicles but this is yet to be seen.

\subsection{Defining the Competition}

The firms that compete with Tesla Motors cannot easily be defined as in the automobile industry many large companies have extensive diversified product offerings and therefore individual products that compete with Tesla cars must be identified. Here is an overview of Tesla Motor's current products in the automobile industry which is later used to assess the markets in which the models effectively compete.

Table 3: Review of Tesla Motor's Current Offerings

\begin{tabular}{|c|c|c|c|c|c|c|}
\hline Product & Production & $\begin{array}{l}\text { Units Sold } \\
\text { (Ordered)* }\end{array}$ & $\begin{array}{r}\text { Cost } \\
\text { (Base } \\
\text { Price } \\
\text { USA) }\end{array}$ & $\begin{array}{r}\text { Range in } \\
\text { mi } \\
\text { (battery } \\
\text { size } \\
\text { KWh)** }\end{array}$ & $\begin{array}{r}\text { Price to } \\
\text { Refuel } * * *\end{array}$ & Class \\
\hline Roadster & $2008-2012$ & 2450 & $\$ 109,000$ & $244(53)$ & $\$ 0-4$ & $\begin{array}{r}\text { Luxury } \\
\text { Roadster }\end{array}$ \\
\hline Model S & $\begin{array}{r}2012- \\
\text { Present }\end{array}$ & 90000 & $\begin{array}{r}\$ 70,000- \\
84,000\end{array}$ & $\begin{array}{c}208(60)- \\
270(95)\end{array}$ & $\$ 0-8$ & $\begin{array}{r}\text { Luxury } \\
\text { Full-Size }\end{array}$ \\
\hline Model X & 2016- & 24000 & $\$ 80,000$ & $257(90)$ & $\$ 0-8$ & $\begin{array}{r}\text { Luxury } \\
\text { CUV/SUV }\end{array}$ \\
\hline Model 3 & 2016- & N/A & $\begin{array}{r}\$ 35,000- \\
40000\end{array}$ & $\sim 200$ & N/A & $\begin{array}{r}\text { Luxury } \\
\text { Compact } \\
\mathrm{Car}\end{array}$ \\
\hline
\end{tabular}

* As of October 2015

** Excluding incentives that vary from state to state

*** $\$ 0$ due to free access to the Tesla Supercharge Network, other prices based on 10 cents a kilowatt hour for off peak charging

The Roadster is a high performance car that is no longer in production and shall therefore be ignored in this report. The Model S and Model X are both full-sized,

International Journal of Management and Applied Research, 2018, Vol. 5, No. 1 
luxury vehicles and the Model 3 is a small luxury vehicle. All Tesla cars are battery electric vehicles which effectively means they are in a unique position in the market as other manufacturers of this vehicle type have so far focused on family vehicles and compact city vehicles. Due to the High price and luxury nature of the Model S and the Model X they naturally find themselves competing with other full sized premium sedans and SUVs. Tesla's reputation and the low environmental impact of its cars means that they also effectively compete within the markets for hybrid electric vehicles, plug in hybrids and the aforementioned companies who currently only offer compact city cars and superminis as battery electric vehicles. The three main markets in which Tesla competes in are therefore the eco car markets which include plug in electrics and hybrid vehicles and the market for luxury sedans. Libby (2014) used information from new vehicle registration data within the United States of America and created a report illustrating the diversity within Tesla's buyer group. The following table to show what Model S buyers owned at the time of purchase.

The data does not stipulate weather the buyers were purchasing the Model $\mathrm{S}$ with the notion of disposing of the original vehicle and this data must therefore be used with caution. However, this table supports the notion that Tesla Motors has innovated to the extent that they have effectively created a product that competes across various markets and against various technologies. This can be seen as brands that are known for producing plug-in electric vehicles, hybrids and fossil fuel powered luxury vehicles are present. Additional information given in the report the report supports this, listing several hybrid Toyota models and the Nissan Leaf, a plug in electric car, as some of the most frequent models owned by Model S buyers (Libby, 2014). The competitors have been identified by analysing Tesla's Model $\mathrm{S}$ buyer group and recent sales data of various eco-friendly cars over the previous 6 months and separated into the markets relevant markets accordingly.

\subsubsection{Tesla Model S vs Main Battery Electric Vehicle Competitors (BEVs)}

Figure 2: Product Value Curve Tesla v BEVs

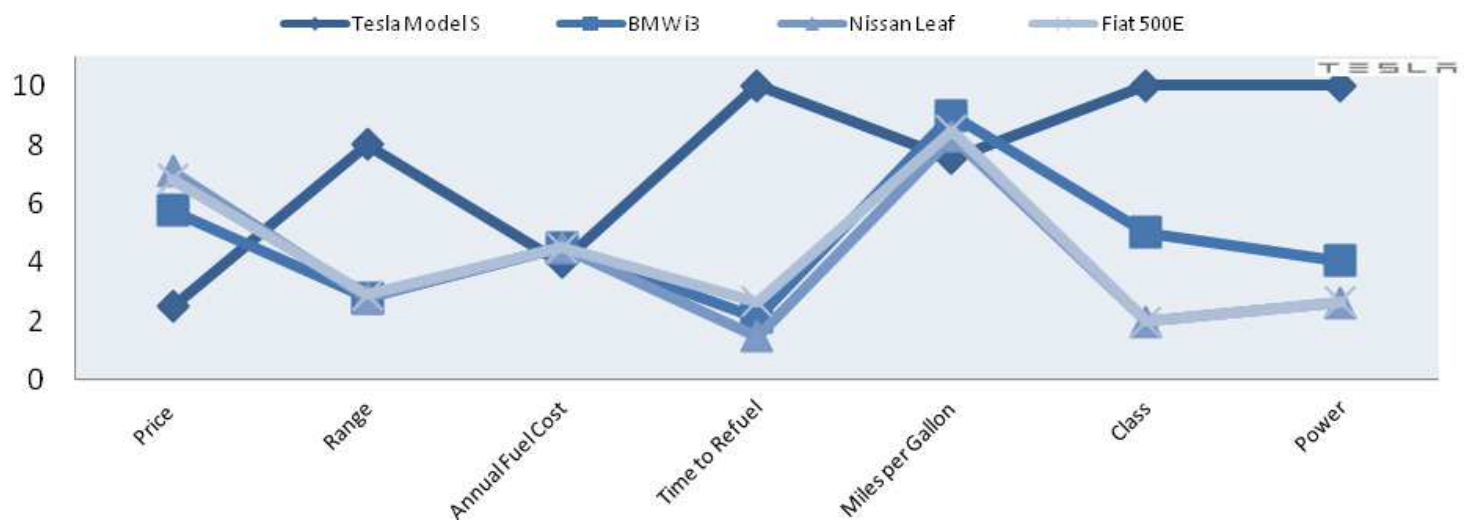

Source: Office of Transportation \& Air Quality, 2015

Battery electric vehicles have some flaws that make people apprehensive when considering them for purchase. Here it can quite clearly be seen that the Tesla Model S

International Journal of Management and Applied Research, 2018, Vol. 5, No. 1 
outperforms its competitors considerably in range, time to refuel, class and power and the annual fuel costs and miles per gallon are in line with the markets strongest competitors. However, Tesla is unable to capitalise on all the potential demand regardless of having a superior product, as the current market leaders have a considerably lower price and are competing with a different class of vehicle altogether.

\subsubsection{Tesla Model S vs Main Hybrid Electric Vehicle Competitors (HEVs)}

Figure 3: Product Value Curve Tesla v HEVs

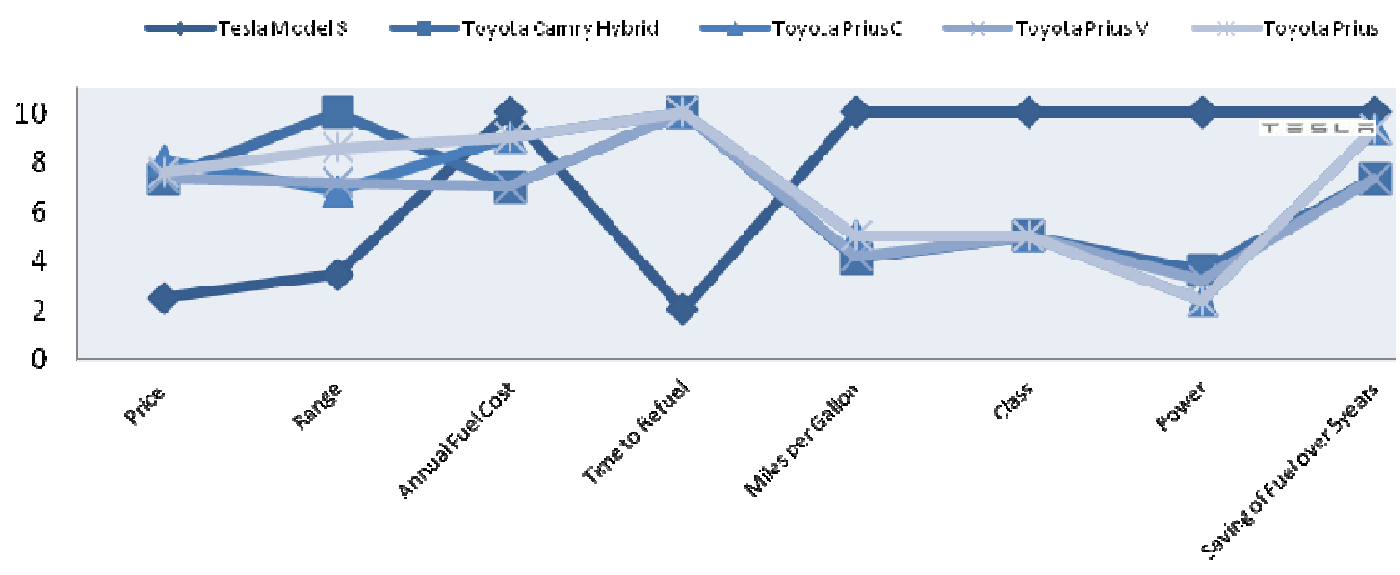

Source: Office of Transportation \& Air Quality, 2015

The main difference between the Model $\mathrm{S}$ and hybrid cars are that hybrids use their petrol engines to charge their batteries and therefore do not need to be plugged in. This can be seen for instance here as the Tesla is uncompetitive in range and time to refuel. Two common issues customers have when considering purchasing a fully electric car, which experts believe are holding back the expansion of the battery electric vehicle market (Musk, 2015). Additionally, the graph shows how the Tesla is again uncompetitive in pricing when compared to hybrid electric vehicles, as with the BEVs this is a question of class. The Model S does outperform its main hybrid competitors considerably in relation to miles per gallon, in addition to power and being more efficient regarding fuel over a 5 year period.

\subsubsection{Tesla Model S vs Main Luxury Sedan Competitors} Figure 4: Product Value Curve Tesla v Luxury Sedans

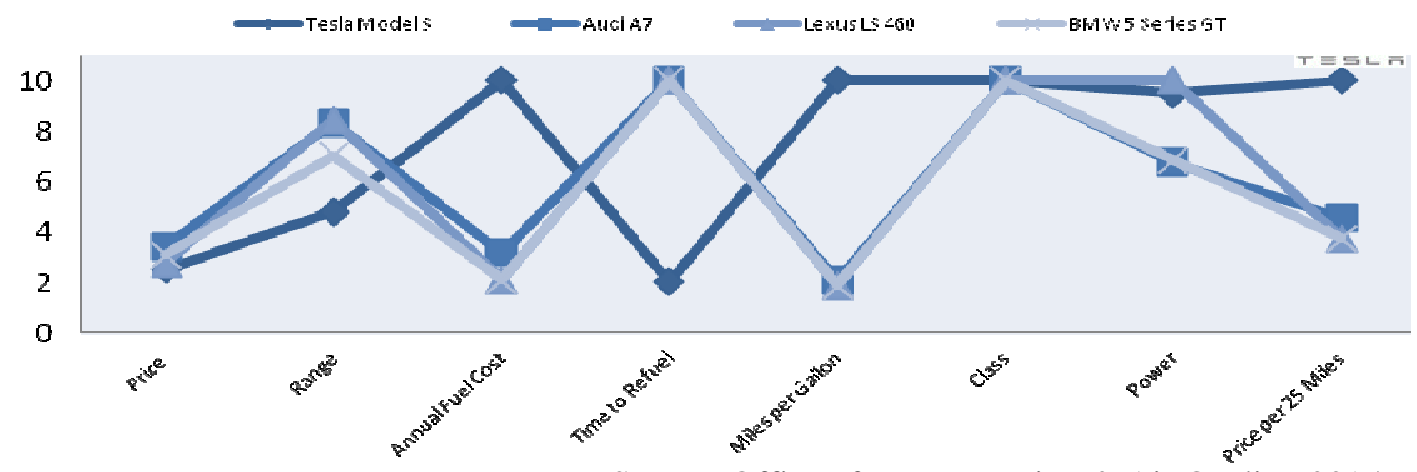

Source: Office of Transportation \& Air Quality, 2015

International Journal of Management and Applied Research, 2018, Vol. 5, No. 1 
Luxury sedans have been included for comparison as they are of the same class of car and similar in price and performance. Battery electric cars emit no emissions other than those emitted by the power plant where the electricity is generated in order to charge them. As electricity is considerably cheaper than petrol in the USA and high performance, luxury vehicles are perceptually known for using above average amounts of fuel there are certain aspects in which the Tesla Model S outperforms its fossil fuel competitors. The annual fuel cost for a Tesla is less than a third of that for a car with similar performance specifications. The time to refuel and range however is again a point where any electric car is less competitive.

\subsubsection{Summary of the Competition}

The product value curves again reinforce the notion that Tesla has manages to create a product that has a rather unique market in a highly competitive industry. The company is able to be competitive in each of the defined markets individually but in each case the Model S offers something that its competitors do not. Tesla's ability to forge a market where customers value both performance and environmental impact has been identified by some competitors and both BMW and Daimler have produced all electric premium vehicles. These cannot currently be taken as serious competitors as they have considerably lower specifications regarding range, time to refuel and miles per gallon for almost twice the cost of the Model $S$ and have therefore been omitted from this report. Concepts of similar all electric luxury vehicles that could one day compete with Tesla have been shown by various auto-manufacturers at global car shows, however these potential entrants are still years away from production and it is unclear how viable the technology presented could be in a production vehicle (DeBord, 2015).

\section{Implications}

The following implications have focus on enhancing Tesla's current competitive abilities in the various markets in which it competes and should not be considered before the Gigafactory becomes at least partly operational so that Tesla can deal with increased demand efficiently.

\subsection{Battery Electric Vehicle (BEV) Market}

Tesla is the current market leader in the BEV market in the USA but the Nissan Leaf is the world's most popular BEV. The market demand as a whole is relatively small when compared with the hybrid or luxury vehicle markets in the USA. Fuel is considerably more expensive in Europe when compared to the USA and this influences buying trends in relation to BEVs.

Potential strategic options:

- For Tesla's sales to increase in the USA, the potential customer base must increase also. This could be achieved through alternative marketing strategies aimed at first time buyers or partnerships with organisations such as The Union

of Concerned Scientists who have recently published that $42 \%$ of American

International Journal of Management and Applied Research, 2018, Vol. 5, No. 1 
households could change to BEVs without changing their lifestyle (UCS, 2013).

- Tesla will only be able to compete with the Nissan Leaf with a car of similar body type. This may most effectively be done through the creation of a partnership with established manufacturers of sub-compact cars.

- Tesla may wish to focus future investments in infrastructure in areas where petrol and deasil is less affordable to the average consumer such as Europe and parts of Asia.

Table 4 summarises strengths and weaknesses of Tesla in BEV market.

Table 4: Strengths and Weaknesses of Tesla

\begin{tabular}{|c|c|}
\hline Benefits & Limitations \\
\hline $\begin{array}{l}\text { Young first time buyers are not used to } \\
\text { the reliance of fossil fuels and are more } \\
\text { likely to adopt new technologies }\end{array}$ & $\begin{array}{l}\text { While increasing the customer base Tesla } \\
\text { will also increase demand for } \\
\text { competitor's vehicle. }\end{array}$ \\
\hline $\begin{array}{l}\text { Through partnerships Tesla technology } \\
\text { can compete with other sub-compact cars } \\
\text { on a global level with limited risk and } \\
\text { limited investment }\end{array}$ & $\begin{array}{l}\text { There are many established competitors in } \\
\text { the sub-compact BEV market. }\end{array}$ \\
\hline $\begin{array}{l}\text { Tesla's superior technology in regards to } \\
\text { battery range, cost of battery production } \\
\text { and charging times could make any sub- } \\
\text { compact car more attractive to consumers } \\
\text { than current market leaders. }\end{array}$ & $\begin{array}{l}\text { Tesla has limited experience creating sub- } \\
\text { compact cars. }\end{array}$ \\
\hline $\begin{array}{l}\text { Europe and Asia already have developed } \\
\text { infrastructure regarding electric cars and } \\
\text { increasing interest in them }\end{array}$ & $\begin{array}{l}\text { Fuel prices are volatile and are not able to } \\
\text { be controlled or accurately predicted by } \\
\text { Tesla in the long term. }\end{array}$ \\
\hline
\end{tabular}

\subsection{Hybrid Electric Vehicle (HEV) Market}

Toyota currently dominates the HEV market with a broad product offering. The HEV market is currently over 4 times the size of the BEV market in the USA. HEVs have range that Tesla is unlikely to be able to compete with without substantial technological advancement. Tesla considered going into the hybrid market by adding a fossil fuel powered range extender to the Model S but decided against it as it was not in line with the company's ethos. Range anxiety and recharge times two common problems in the BEV market are not applicable in the HEV market.

Potential strategic option includes forming a partnership with an established producer of hybrid vehicles to compete directly with Toyota models. Table 5 summarises strengths and weaknesses of Tesla in HEV market.

Table 5: Benefits and Limitations

\begin{tabular}{ll}
\hline Benefits & Limitations \\
\hline Forming a partnership would not tarnish & There is potential for Tesla to cannibalise \\
Tesla's brand with regards to the its sales of other models if the Tesla
\end{tabular}

International Journal of Management and Applied Research, 2018, Vol. 5, No. 1 
company's attitude towards fossil fuels.

Decreased risk when forming a partnership as knowledge and costs can be shared between firms

Tesla's superior technology in regards to battery range, cost of battery production and charging times could make any hybrid car more attractive to consumers than current market leaders.

Tesla has previous experience operating as an original equipment manufacturer.

A Tesla hybrid has the potential to move into uncontested market space of a high performance luxury hybrid in marketed and priced correctly. hybrid is of a comparable class to the Model S

Additional competitors may have to be accounted for that are not covered in this report.

The Hybrid car industry is currently dominated by the world's largest automobile manufacturer.

Toyota has the capital to adapt to a changing market rapidly.

\subsection{Luxury Sedan Market}

The luxury sedan market is growing at a faster rate than the automobile market as a whole in the USA and China. The market is dominated by the German big three (BMW, Audi, Mercedes) in addition to Toyota owned Lexus. Tesla's Model S is better than or equal to its similarly priced competitors in all factors apart from range and the time it takes to refuel.

Potential strategic options:

- Emulate the success surrounding the German big three by focusing on performance and highlighting the low depreciation of Tesla products.

- Perform a cost benefit analysis of competing within motorsports in order to strengthen brand image.

- Again form a partnership with organisations such as The Union of Concerned Scientists to highlight the cost savings both financially and environmentally while emphasising competitive performance.

- Develop a Blue Ocean Marketing approach emphasizing both performance and sustainability aimed at young professionals (Kim and Mauborgne, 2014).

Table 6 summarises strengths and weaknesses of Tesla in Luxury car market

Table 6: Benefits and Limitations of Tesla in Luxury car market

\begin{tabular}{lrl}
\hline Benefits & Limitations \\
\hline $\begin{array}{l}\text { Tesla already differentiates itself } \\
\text { considerably in this market. }\end{array}$ & $\begin{array}{l}\text { Falling fuel prices in the USA means } \\
\text { fossil fuel powered cars are becoming } \\
\text { cheaper to }\end{array}$ \\
$\begin{array}{l}\text { Motorsports could potentially highlight } \\
\text { The German big three have extremely }\end{array}$ \\
$\begin{array}{l}\text { Tesla's engineering capabilities in } \\
\text { addition to being a platform for }\end{array}$ may not be easily emulated
\end{tabular}
performance innovation. (Formula $\mathrm{E}$ an 
emerging sport)

Partnerships with organisations that Participating in motorsport may divert promote BEVs will be relatively inexpensive.

Focusing specifically on young professionals focuses on groups that are typically part of the innovators and early adopters and are more likely to embrace resources away from the main focus of the company.

Blue Ocean Marketing Strategy must be implemented correctly to effectively create an uncontested market of the environmentally conscious car enthusiast. new technology (Roger, 2003).

\section{Conclusion}

Tesla Motor's was established by creating an uncontested niche market for affluent sports car lovers who were interested in the company's vision regarding sustainability and fossil fuels. The firm has now expanded its product range to include the Model S which competes effectively in the battery and hybrid electric vehicle markets and the luxury sedan market. Tesla utilises the Roger's diffusion of innovation theory (2003) with the aim of developing products to reach the mass market and controls costs through vertical integration, product innovation and strategic partnerships. In order for the company to continue to compete effectively it must continue to seek uncontested market spaces and promote its unique product specifications in addition to developing its brand as a luxury electric car manufacturer. Tesla should also seek to promote the battery electric vehicle market as a whole by incorporating relevant partnerships into the firm's corporate strategy.

\section{References}

1. Autoalliance (2015), U.S. car sales from 1951 to 2014 (in units), [Online] Available at: http://www.statista.com/statistics/199974/us-car-sales-since-1951/ (Accessed on: 30th October 2015)

2. Chan, C.C. and Wong, Y.S. (2004), "Electric vehicles charge forward, Power and Energy Magazine", IEEE, Vol. 2, No. 6, pp. 24-33. https://doi.org/10.1109/MPAE.2004.1359010

3. Cobb, J. (2015), September 2015 Dashboard [Online] Available at: http://www.hybridcars.com/september-2015-dashboard/ (Accessed on: 1st November 2015)

4. Cuthbertson, A. (2014), Tesla to Create World's Largest Lithium-ion Battery Factory [Online] Available at: http://www.ibtimes.co.uk/tesla-create-worldslargest-lithium-ion-battery-factory-1441095 (Accessed on: 1st November 2015)

5. DeBord, M. (2015), Tesla might finally be facing competition from powerful rivals [Online] Available at: http://www.techinsider.io/tesla-might-have-to-worry-2015-9 (Accessed on: 8th November 2015)

6. Economist. (2009), A giant falls [Online] Available at: http://www.economist.com/node/13782942 (Accessed on: 1st November 2015)

International Journal of Management and Applied Research, 2018, Vol. 5, No. 1 
7. EDTA. (2015), Electric Drive Sales Dashboard [Online] Available at: http://electricdrive.org/index.php?ht=d/sp/i/20952/pid/20952 (Accessed on: 31st October 2015)

8. GoodCarBadCar.net. (2015), U.S. luxury car market share in 2014, by brand [Online] Available at: http://www.statista.com/statistics/287620/luxury-vehiclesunited-states-premium-vehicle-market-share/ (Accessed on: 30th October 2015)

9. IHS Automotive. (2014), SUVs and Crossovers Overtake Sedans to Become Most Popular Vehicle Body Style in the U.S. [Online] Available at: http://press.ihs.com/press-release/automotive/suvs-and-crossovers-overtakesedans-become-most-popular-vehicle-body-style- (Accessed on: 31st October 2015)

10. Kim, W. and Mauborgne, R. (2014), Blue Ocean Strategy: How to Create Uncontested Market Space and Make the Competition Irrelevant, Boston: Harvard Business School Publishing Corporation

11. Libby, T. (2014), Who is buying the Tesla Model S? [Online] Available at: http://blog.ihs.com/who-is-buying-the-tesla-model-s [Accessed on 31st October 2015]

12. Murtha P., (2015) BMW, Mercedes Vie for U.S. Sales Crown in Upbeat Premium Car Market [Online] Available at: http://www.jdpower.com/cars/articles/autosales/bmw-mercedes-vie-us-sales-crown-upbeat-premium-car-market (Accessed on: 1st November 2015)

13. Musk, E. (2015), Visions for Tesla, the auto industry and self-driving Teslas (Interview in Denmark). [Online] Available from:

https://www.youtube.com/watch?v=bl5vLC3Xlgc (Accessed on: 30th October 2015)

14. Musk, E. (2004), The Secret Tesla Motors Master Plan (just between you and me) [Online] Available at: https://www.tesla.com/en_GB/blog/secret-tesla-motorsmaster-plan-just-between-you-and-me (Accessed on: 30th October 2015)

15. Office of Transportation \& Air Quality. (2015), Compare Hybrids Side-by-Side [Online] Available at: http://www.fueleconomy.gov/feg/hybrids.jsp (Accessed on: 8th November 2015)

16. Pyper J., (2015), As European Electric Vehicle Sales Spike, Demand Slows in the $U S$ [online] Available at: http://www.greentechmedia.com/articles/read/europeanev-sales-spike-as-the-u.s.-market-lags (Accessed on: 30th October 2015)

17. Read, R. (2013), GM Follows Tesla's Lead, Plans To Sell Directly To Online Shoppers. [Online] Available at:

http://www.thecarconnection.com/news/1087492_gm-follows-teslas-lead-plans-tosell-directly-to-online-shoppers (Accessed on: 2nd November 2015)

18. Rogers, E.M. (2003), Diffusion of Innovations. 5th ed. New York: The Free Press.

19. Supercharge. (2015) Supercharge map [Online] Available at: http://supercharge.info/ (Accessed on: 10 November 2015)

International Journal of Management and Applied Research, 2018, Vol. 5, No. 1 
20. Tesla Motors. (2010), Press Release, Strategic partnership: Daimler acquires stake in Tesla. [Online] Available at: https://www.tesla.com/en_GB/blog/strategicpartnership-daimler-acquires-stake-tesla (Accessed on: 22 October 2015)

21. Tesla Motors. (2014a), Press Release, Panasonic and Tesla Sign Agreement for the Gigafactory. [Online] Available at: https://www.tesla.com/en GB/blog/panasonicand-tesla-sign-agreement-gigafactory (Accessed on: 23 October 2015)

22. Tesla Motors. (2014b), Planned 2020 Gigafactory Production Exceeds 2013 Global Production [Online] Available at: https://www.tesla.com/sites/default/files/blog_attachments/gigafactory.pdf (Accessed on: 8 November 2015)

23. Tesla Motors. (2015) Investors Overview [Online] Available at: https://ir.tesla.com/\#tab-quarterly-disclosure (Accessed on: 30 October 2015)

24. Trudell, C. and Ohnsman, A. (2014) Why the Tesla-Toyota Partnership ShortCircuited [Online] Available at: http://www.bloomberg.com/bw/articles/2014-0807/tesla-toyota-deal-to-develop-electric-suv-fizzles (Acessed on: 22nd October 2015)

25. UCS. (2013) Millions of Americans Could Use an Electric Vehicle [Online] Available at: http://www.ucsusa.org/clean_vehicles/smart-transportationsolutions/advanced-vehicle-technologies/electric-cars/bev-phev-range-electriccar.html\#learn (Accessed on: 20th November 2015). 